\title{
Generation Y Consumers' Value Perceptions toward Apparel Mobile Advertising: Functions of Modality and Culture
}

\author{
Wanmo Koo (Corresponding author) \\ Department of Retail, Hospitality, and Tourism Management, University of Tennessee \\ 1215 W. Cumberland Ave., 110 Jessie Harris Building, Knoxville, TN 37996-1911, USA \\ Tel: 1-940-300-8616 E-mail: wkoo@utk.edu
}

Dee K. Knight

School of Merchandising and Hospitality Management, University of North Texas

1155 Union Circle, \#311100, Denton, TX 76203-5017, USA

Tel: 1-940-565-2433Ｅ-mail: Dee.Knight@unt.edu

Kiseol Yang

School of Merchandising and Hospitality Management, University of North Texas

1155 Union Circle, \#311100, Denton, TX 76203-5017, USA

Tel: 1-940-369-8210 E-mail: kyang@smhm.unt.edu

Zheng Xiang

School of Merchandising and Hospitality Management, University of North Texas

1155 Union Circle, \#311100, Denton, TX 76203-5017, USA

Tel: 1-940-369-7680Ｅ-mail: philxz@unt.edu

Received: December 21, $2011 \quad$ Accepted: January 4, 2012 Published: April 1, 2012

doi:10.5539/ijms.v4n2p56 URL: http://dx.doi.org/10.5539/ijms.v4n2p56

\begin{abstract}
This study investigates Generation Y consumers` different value perceptions toward apparelmobile advertising according to cultures (i.e., The United States vs. South Korea) and modalities (short message service vs. multimedia messaging service). Results indicate that the entertainment value was perceived differently for two modalities: short message service (SMS) versus multimedia messaging service (MMS). In addition, the values of entertainment, informativeness, irritation, and credibility were perceived differently by two cultures U.S. and Korea.
\end{abstract}

Keywords: Mobile advertising, SMS, MMS, Cross culture, Entertainment, Informativeness, Irritation, Credibility, Modality

\section{Introduction}

The Internet continues to transform the retail industry (Ngai \& Gunasekaran, 2007), and E-commerce has grown exponentially due to the advantages of transactional convenience, ease of renewing information, and highly interactional features. Despite its advantages, e-commerce is constrained due to fixed Internet lines and the restricted range of wireless. Mobile phones, however, overcome these limitations through unlimited wireless capability (Ngai \& Gunasekaran, 2007), which frees consumers from the limitations of fixed-line personal computers (Clarke, 2001). By 2008, there were approximately four billionmobile phone subscribers around the world ("Internet indicators: Subscribers, users, and broadband subscribers," 2009). Worldwide mobile phone distribution and severaladvantagessuch as personalization, ubiquity, convenience, and localization indicate the growth potential of mobile advertising. In fact, mobile advertising (hereafter, M-advertising) expenditure 
reached US\$743.1 million in 2010, an increase of 79 percent over the previous year, and is expected to increase to US\$1.1 billion in 2011 ("Industry trends spur big mobile ad spending," 2010).

Gen Y consumers, born between 1977 and 1997 (Dulin, 2005), have widely been studied for the mobile technology because this consumer cohort who has never had a chance without modern electronic devices is highly sophisticated in technology (Herbison \& Boseman, 2009). Not surprisingly, the mobile phone is the favorite device for Gen Y consumers worldwide (Venkatacharya, Rice, \& Bezuayehu, 2009). These technologically savvy consumers receive remarkable attention from apparel retailersbecause of their heavy expenditure on apparel and consumer behavior related to apparel purchase (Sullivan \& Heitmeyer, 2008). In 2008 , Gen Y consumers spent US $\$ 33.7$ billions on apparel, and this spending was approximately US $\$ 4-\$ 17$ billions higher than that of any other age group (Tran, 2008). These consumers are knowledgeable about brands, tend to be fashion conscious (Sullivan \& Heitmeyer, 2008), and influence about 81 percent of their families apparel purchases (O`Donnell, 2006).

M-advertising uses both modalities to communicate with consumers: short message service (SMS) and multimedia message service (MMS) (Jaffee, 2007). SMS and MMS are quite different in that SMS can only support text, while MMS can support not only text but also image, audio, and video. Numerous researchers have examined consumers` attitudes toward SMS advertising (Cheng et al., 2009; Tsang, Ho, \& Liang, 2004; Carroll et al., 2007; Rettie, Grandcolas, \& Deakins, 2005). However, MMS advertising has attracted less empirical attention because of newness and relatively lower usage than SMS advertising (Cheng et al., 2009). In the case of apparel advertising, MMS advertisingcan well depict images of apparel in magazines and newspapers. Furthermore, because consumer involvement with M-advertising differs for different modalities (Nasco \& Bruner, 2008), academics need to turn critical attention to whether and how modality (SMS vs. MMS) of M-advertising influences Gen Y consumers' attitudes.

Due to the intensively saturated domestic market, U.S. apparel retailers have expanded into international marketswhere markets are less saturated $(\mathrm{Ng}, 2010)$. In expanding to international markets, many U.S. apparel retailers have targeted Gen Y consumers because this cohort consists of first true consumers having a global outlook (Heskett, 2007). However, significant differences in message and communication preferences exist between eastern and western cultures (Hofstede \& Hofstede, 2005; Taylor, Miracle, \& Wilson, 1997). This implies that advertising values may vary by culture.

Tsang et al. (2004) and Xu (2006) demonstrated that advertising values can ultimately influence their behavior; thus, it is critical for advertisers to identify how advertising values are perceived by their target consumers so that they can develop effective methods of communicating these values to their target markets. However, as mentioned above, advertising value perceptions can be different from modality and culture. Therefore, the purposes of this study were toexamine different perceptions of apparel mobile advertisingvalue components (i.e., entertainment, informativeness, irritation, and credibility) by modalities (i.e., SMS vs. MMS) and culture (i.e., U.S. vs. Korea).

\section{Literature Review}

\subsection{M-advertising in the Apparel Industry}

M-advertising has been abundantly used in the apparel industry. Apparel retailers are utilizing themobile platform that offers the advantages of personalization, ubiquity, convenience, localization (Clarke, 2001), and interactivity (Haghirian, Madlberger, \& Tanuskova, 2005). Apparel advertisers can utilize these advantages to establish and maintain customer relationships and greater consumer responses to promotional activities (Okazaki, 2005). Direct response using a mobile platform allows consumers to respond easily by accessing promotions and/or contacting apparel companies directly. Most importantly, these new advertising channels can strengthen both brand identity (Rettie, Grandcolas, \& Deakins, 2005; Okazaki, 2005) and effectiveness of existing advertising channels (Nysveen et al., 2005).

\subsection{Advertising Values Determinants of Attitudes toward Mobile Advertising}

Two widely-used consumer behavior theories provide the research framework for this study. First, the Theory of Reasoned Action (TRA) (Fishbein \& Ajzen, 1975) contends that a person's behavioral intention depends upon the person's attitudes and subjective norms. Second, the Technology Acceptance Model (TAM), used extensively in empirical studies of e-commerce, suggests that the belief-attitude-intention-behavior relationship explains technology acceptance among users. Based on the theories, Tsang et al. (2004) and Xu (2006) demonstrated that advertising values can be determinants of attitudes toward mobile advertising which, in turn, influence the use of the mobile advertising. Since consumers' perceptions of advertising values can ultimately influence their 
behavior, it is critical for advertisers to identify what advertising values their target consumers perceive important and develop effective methods of communicating these values to their target markets. The literature reveals that four advertising values (i.e., entertainment, informativeness, irritation, and credibility) affect consumer attitudes toward M-advertising.

\subsubsection{Entertainment}

Perceived entertainment in advertisements can be defined as an amusing and pleasant experience through the use of advertising (Eighmey \& McCord, 1998). Entertaining advertisements carry commercial messages that elicit consumers' positive feelings and thus meet the demand of those who seek to obtain playful experience. Since entertaining experience enable consumers to be aesthetically enjoyed and emotionally released, the entertainment advertising value cangenerate positive attitudes toward the advertising (Ducoffe, 1995; McQuail, 1983).

\subsubsection{Informativeness}

Informativeness is an advertising attribute that provides helpful information, and information transferred through mobile phones should exhibit qualitative characteristics such as timeliness and accuracy (Siau \& Shen, 2003). Furthermore, Haghirian et al. (2005) and Tsang et al. (2004) demonstrated that informativeness mainly forms M-advertising values. Enhancement of informativeness in advertising can decrease deceptiveness in advertising (Ducoffe, 1995). A Gallop Organization study of human nature and behavior suggests that consumers generally have positive attitudes toward informative advertising (Brackett \& Carr, 2001).

\subsubsection{Irritation}

Irritation in advertising generates annoyance, discontent, and intolerance, and even a small irritation can impair the effectiveness of advertising (Aaker \& Bruzzone, 1985). Irritation can be caused by advertisements considered to be manipulative or deceptive (Chakrabarty \& Yelkur, 2005).Consumers describe advertising using complex, annoying, or offending techniques as irritating. Irritation results in negative attitudes toward advertising (Pelsmacker \& Bergh, 1998) and brands (Chakrabarty \& Yelkur, 2005), and the level of negativism as a result of irritating advertising varies by brand. Furthermore, advertising irritation is predictive of perceived value of Internet (Brackett \& Carr, 2001) and mobile (Haghirian et al., 2005) advertising. Attitudes toward web advertising are negatively related to perceived irritation of web advertising (Chakrabarty \& Yelkur, 2005).

Tsang et al. (2004) reported that perceived irritation of mobile advertising affected consumers' attitudes toward mobile advertising.Undoubtedly, consumers' perception toward an irritating advertisement should be negative.

\subsubsection{Credibility}

Credibility in advertising is the degree to which consumers trust retailers' claims about brands (Mackenzie \& Lutz, 1989) and their confidence in the honesty and plausibility of the advertisement (Chowdhury et al., 2006). Moldovan (1985) found that credibility is a major factor that can explain not only the variation of persuasiveness of advertising but also general responses toward advertising. In the e-commerce area, credibility also is a direct predictor of attitudes toward internet advertising (Brackett \& Carr, 2001). Credibility also plays an important role in mobile advertising. Haghirian et al. (2005) reported a positive relationship between credibility and consumers' perceived value of mobile advertising.

\subsection{Modality}

Both SMS (short message service) and MMS (multimedia messaging service) are used in M-advertising, but they have different functions. SMS messages can be no more than 160 characters in length and are limited to text, while MMS messages can utilize digital photographs, video, and audio, in addition to text.

In the web environment, pictorial banners elicit more positive consumer responses compared to their text-only counterparts (Ryu et al., 2007). Modality also can impact consumer responses to messages using mobile technology (Nasco \& Bruner, 2008). Advertising message recall is improved when streaming video with audio is used. Thus, there exists a need to understand the consumer responses toward wireless information using a variety of modalities, such as text, audio, images, and streaming video. Cheng et al. (2009) examined consumers' attitudes toward advertising in the contexts of Internet websites, e-mail, SMS, and MMS. Their findings suggest that MMS advertising largely contains informative andentertainingfeatures compared to other media. Therefore, Gen Y consumers' value perceptions toward M-advertising could differ according to different modalities. However, no studies have examined consumers' perceptions of apparel advertising using various mobile modalities. Thus, the following hypotheses are proposed:

H1: Entertainment value perceptions toward apparel M-advertising will differ between SMS and MMS.

H2: Informativeness value perceptions toward apparel M-advertising will differ between SMS and MMS. 
H3: Irritation value perceptions toward apparel M-advertising will differ between SMS and MMS.

H4: Credibility value perceptions toward apparel M-advertising will differ between SMS and MMS.

\subsection{Culture}

The United States and Korea are the focal national cultures for this study. These two markets are especially relevant in studies of M-advertisingbecause they have fast-growing mobile penetration rates (Choi, Hwang, \& McMillan, 2008) but culturally different. The U.S. can be categorized as a highly individualistic culture, while Korea is a collectivistic country (Bang et al., 2005; Cho et al., 1999; Hofstede \& Hofstede, 2005; Taylor, Miracle, $\&$ Wilson, 1997). Specifically, U.S. consumers scored 91 out of 100, and Korean consumers registered 18 out of 100 on the Individualist dimension of Hofstede's Model of National Cultures (Hofstede \& Hofstede, 2005).

Collectivist cultures (e.g., Korea) rely upon non-verbal communications to convey meaning, while individualistic cultures (e.g., United States) prefer structured, detailed messages that rely upon words and symbols for meaning (Park \& Jun, 2003). In a cross-culture comparison of television advertising messages, U.S. Gen Y consumers preferred information-rich commercials compared to their Korean counterparts who preferred laconic information (Taylor et al., 1997). Also, expressions of individualism in domestic brand television commercials are more prominent in the United States than in Korea, while commercials incorporating conversations among individuals are more prevalent in Korea than in the United States (Cho et al., 1999).

Researchers have examined advertising in other media. In a study of magazine advertisements, U.S. companies typically utilized rational appeals, while Korean advertisements relied on emotional appeals (Bang et al., 2005). Therefore, it can be postulated that U.S. and Korean Gen Y consumers value perceptions toward apparel M-advertising will differ. Thus, the following hypotheses are tested:

H5: Entertainment value perceptions toward apparel M-advertisingwill differ between U.S. and Korean Gen Yconsumers.

H6: Informativeness value perceptions toward apparel M-advertising will differ betweenU.S. and Korean Gen Y consumers.

H7: Irritation value perceptions toward apparel M-advertising will differ between U.S. and Korean Gen Y consumers.

H8: Credibility value perceptions toward apparel M-advertising will differ between U.S. and Korean Gen Y consumers.

\section{Methods}

\subsection{Instrument}

Existing scales from the relevant literature were adapted to create self-administered questionnaires. Ducoffe's (1996) scales were adapted to measure the three advertising values of entertainment, informativeness, and irritation; Mackenzie and Lutz's (1989) scales for measuring credibility in the context of general advertising were modified for the specific context of mobile advertising. All items were internally consistent with Cronbach`s alpha ranging from. 72 to .90 . Seven point Likert-type scales $(1=$ strongly disagree to $7=$ strongly agree) measured responses to each item.See Table 1.

The instrument was translated into Korean and back-translated to ensure consistent meaning of the translated version. Two versions of the instrument (i.e., SMS, MMS) were developed and distributed in both the United States and Korea. Explanations and examples of SMS or MMS apparel M-advertising provided in the questionnaire. Demographic and general consumption characteristics were solicited to obtain respondents' age, gender, education, monthly expenditures on apparel and apparel-related products, and monthly expenditures on mobile services.

\subsection{Data Collection}

Instruments were distributed to 430 college students in Spring 2010 during regularly scheduled classes at a major U.S. $(\mathrm{n}=204)$ and Korean $(\mathrm{n}=226)$ university (see Table 2$)$. The two universities have quite similarcharacteristics except cultural differences in that students were in the same major (i.e., fashion merchandising); in addition, the two universities were in the almost identical size. Of those, 407 instruments were deemed usable and retained for data analyses. Gen Y participants in this study aged between 17 and 30 ( $M$ $=22.6$ ), and all participants reported owning a mobile phone. Female participates represented a majority in both the United States $(88 \%)$ and Korea $(68 \%)$. Interestingly, a higher percentage of Korean participants $(55 \%)$ received apparel M-advertisements compared to U.S. participants (28\%) (see Table 3). 


\subsection{Data Analyses}

Descriptive statistics were used to develop a profile of participants.Gen Y consumers` different perceptions of mobile advertising values by modalities and cultures were assessed using two-way analysis of variance (ANOVA). All statistical analyses were conducted using the Statistical Package for Social Science (SPSS) version 18.0.0.

\section{Results}

\subsection{Modality and Cultural Effects}

The overall two-way ANOVA models were significant $(p<.05)$ in all cases. As for modality main effects, perceived entertainment differed by modality $[F(1,403)=4.802, p<.029]$. Specifically, respondents perceived MMS more entertaining than SMS apparel M-advertising $(M=2.95 / 3.24)$. However, there was no significant effect of modality onthe perceived attributes of informativeness, irritation, and credibility; thus, only hypothesis 1 was supported.

As for cultural main effects, perceived entertainment differed between U.S. and Korean participants $[F(1,403)=$ 9.512, $p<.002]$. U.S. Gen Y consumers perceived apparel M-advertising as more entertaining than did Korean Gen Y consumers $(M=3.30 / 2.90)$. Culture also affected perceived informativeness $[F(1,403)=65.916$, $p<.000]$ with the mean of U.S. Gen Y consumershigher than that of Korean Gen Y consumers $(M=4.65 / 3.71)$. There was a significant effect of culture on perceived irritation of apparel M-advertising $[F(1,403)=84.052$, $p<.000]$; U.S. Gen Y consumers considered apparel M-advertising less irritating than did Korean Gen Y consumers $(M=3.79 / 4.77)$. Finally, culture affected perceived credibility of apparel M-advertising $[F(1,403)=$ 72.474, $p<.000$ ], with U.S. Gen Y consumers perceiving apparel M-advertising as more credible than did Korean Gen Y consumers $(M=3.95 / 2.87)$. Accordingly, hypotheses 5 to 8 were supported. All results were provided in Table 4, and, for reference, specific mean scores were presented in Table 5.

\section{Discussionsand Conclusions}

The study investigated different perceptions of advertising values according to modality and culture. Results indicate that only perceived entertainment differs between SMS and MMS apparel M-advertising. This finding is not surprising in that MMS apparel M-advertising can support video with images of merchandise, music, color, and audio in addition to text. These multimedia tools can affect multiple senses simultaneously and make advertising messages more entertaining (Siau \& Shen, 2003).

Apparel retailers can make advertisingrecipients entertaining by using MMS advertising, and entertainment was the chief advertising value that can generative positive attitudes toward advertising which can in turn increase the recipients` purchase intention (Tsang et al., 2004; Xu, 2006). Furthermore, M-advertising that is perceived as entertaining canbe spread outby Gen Y consumers who may subsequently share it with family and friends, extending the reach of the message. Regarding the above, the relatively higher costs of MMS advertising could be cost effective.

The study also examined thecultural differences between U.S. and Korean Gen Y participants' perceptions of apparel M-advertising values. U.S. Gen Y participants, compared to their Korean counterparts, perceived apparel $\mathrm{M}$-advertising as entertaining. This finding may be indicative of a greater number of Korean participants receiving M-advertising compared to U.S. participants (See Table 2) because the familiarity with the technology may diminish the entertaining feeling generated by using innovative technology like M-advertising (Wei \& Leung, 1998). In other words, since U.S. Gen Y consumers have less experienced M-advertising than Koreans, they are likely to feel entertainment by experiencing the new way of receiving advertising via their mobile phones.

U.S. Gen Y consumers regarded apparel M-advertising as informative more than did Korean Gen Y consumers. Due to costs and limitations (e.g., screen size), most apparel M-advertising consists of promotional messages that are clear and explicative. This finding supports the notion that U.S. consumers living in individualistic cultureprefer messages that convey clear and concise information (Hofstede \& Hofstede, 2005; Park \& Jun, 2003).

In addition, U.S. Gen Y participants were more likely to regard apparel M-advertising as credible than were Korean Gen Y participants. Advertising messages familiar to recipients are perceived as credible (Self, 1996). Taylor et al. (1997) indicated that U.S. television commercials largely used rational appealsthan Korean television commercials did, and this fact implies that U.S. consumers are used to apparel M-advertising generally made with logical senses. 
Fewer U.S. than Korean Gen Y consumers described apparel M-advertising as irritating. The result could be caused by comparative preferences of other advertising values (i.e., entertainment, informativeness, and irritation) becauseconsumers perceived less irritation toward $\mathrm{M}$-advertisingthat was described as entertaining, informative, and credible (Xu, 2006). Namely, as U.S. Gen Y consumers perceive apparel M-advertising as more entertaining, informative, and credible than do Korean consumers, U.S. Gen Y consumers may relatively perceive less irritating compared to Korean Gen Y consumers.

These results offer valuable insights for apparel companies. As companies expand into international markets, understanding national cultural differences in terms of effective M-advertising is vitally important. It is clear that while Gen Y consumers worldwide exhibit a common affinity for mobile devices, national cultural differences do exist and must be considered when developing and implementing M-advertising strategies. Understanding the advertising preferences of Gen Y consumers in these two focal markets (i.e., the United States and Korea) suggests that localized M-advertising messages should be offered to Gen $\mathrm{Y}$ consumers in different cultural-bases.

\section{Limitationsand Future Research}

Given the exploratory nature of this study, some limitations should be noted. The purposeful convenience sample may not be representative of Generation Y consumers who are familiar with M-advertising. In addition, the study was conducted in the apparel specific context. Thus, caution must be used in generalizing the findings.

Translation for cross-cultural studies is challengingbecause complex factors influence the processes of translation and back translation (Brislin, 1970). Accordingly, the possibility exists for translation errors that may impact reliability of the findings. Finally, not all participants received apparel M-advertising, which may have affected the results. A future study that can offer real M-advertisements to participants as stimuli can generate more reliable results than this study.

There are some recommendations for future research. The representative countries in this study, the United States and Korea, are highly individualistic and collectivistic respectively. Future studies should consider other national cultures to inform businesses that are expanding globally and using M-advertising. Although this study was conducted in an apparel specific context, this study could be replicated in other industries such as travel, food, or automobiles.

\section{References}

Aaker, D., \&Bruzzone, D. E. (1985). Causes of irritation in advertising. Journal of Marketing, 49. 47-57. http://dx.doi.org/10.2307/1251564

Bang, H. K., Raymond, M. A., Taylor, C. R., \& Moon, Y. S. (2005). A comparison of service quality dimensions conveyed in advertisements for service providers in the USA and Korea: A content analysis. International Marketing Review, 22(3). 309-326. http://dx.doi.org/10.1108/02651330510602222

Brackett, L., \& Carr, J. B. (2001). Cyberspace advertising vs. other media: Consumer vs. mature student attitudes. Journal of Advertising Research, 41(5). 23-32.

Brislin, R. W. (1970). Back-translation for cross-cultural research. Journal of Cross-Cultural Psychology \& Marketing, 1(3). 185-216.

Carroll, A., Barnes, S. J., Scornavacca, E., \& Fletcher, K. (2007). Consumer perceptions and attitudes toward SMS advertising: Recent evidence from New Zealand. International Journal of Advertising, 26(1). 79-98.

Chakrabarty, S., \& Yelkur, R. (2005). The effects of ad irritation on brand attitudes. Journal of Promotion Management, 11(2/3). 37-48. http://dx.doi.org/10.1300/J057v11n02_04

Cheng, J. M., Blankson, C., Wang, E. S., \& Chen, L. S. (2009). Consumer attitudes and interactive digital advertising. International Journal of Advertising, 28(3). 501-525. http://dx.doi.org/10.2501/S0265048709200710

Cho, B., Kwon, U., Gentry, J. W., Jun, S., \& Kropp, F. K. (1999). Cultural values reflected in theme and execution: A comparative study of U.S. and Korean television commercials. Journal of Advertising, 8(4), 59-73.

Choi, Y. K., Hwang, J. S., \& McMillan, S. J. (2008). Gearing up for mobile advertising: A cross-cultural examination of key factors that drive mobile messages home to consumers. Psychology \& Marketing, 25(8), 756-768. http://dx.doi.org/10.1002/mar.20237

Chowdhury, H., Parvin, N., Weitenberner, C., \& Becker, M. (2006). Consumer attitude toward mobile advertising in an emerging market: An empirical study. International Journal of Mobile Marketing, 1(2), 33-42.

Clarke, I. (2001). Emerging value proposition for m-commerce. Journal of Business Strategies, 18(2), 133-148. 
Ducoffe, R. H. (1995). How consumers assess the value of advertising. Journal of Current Issues and Research in Advertising, 17(1), 1-18.

Ducoffe, R. H. (1996). Advertising value and advertising on the web. Journal of Advertising Research, 36(5), 21-35.

Dulin, L. (2005). Leadership preferences of a Generation Y cohort: A mixed method investigation. Doctoral dissertation. ProQuest Dissertations and Theses database database. (UMI No. 1434728).

Eighmey, J., \& McCord, L. (1998). Adding Value in the Information Age: Uses and Gratifications of Sites on the World Wide Web. Journal of Business Research, 41(3), 187-194. http://dx.doi.org/10.1016/s0148-2963(97)00061-1

Fishbein, M., \& Ajzen, I. (1975). Belief, attitude, intention, and behavior: An introduction to theory and research Reading. MA: Addison-Wesley.

Haghirian, P., Madlberger, M., \& Tanuskova, A. (2005). Increasing advertising value of mobile marketing - An empirical study of antecedents. Paper presented at the 38th Hawaii International Conference on System Sciences. http://dx.doi.org/10.1109/HICSS.2005.311

Herbison, G., \& Boseman, G. (2009). Here they come-Generation Y. Are you ready? Journal of Financial Service Professionals, 63(3), 33.

Heskett, J. (2007). How will Millennials manage? Working Knowledge Newsletter. Harvard Business School.

Hofstede, G., \& Hofstede, G. J. (2005). Cultures and organizations: Software of the mind. New York, NY: McGraw-Hill.

Industry trends spur big mobile ad spending. (2010). [Online] Available: http://www.scribd.com/doc/40075470/Industry-Trends-Spur-Big-Mobile-Ad-Spending-25-10-10

Internet indicators: Subscribers, users, and broadband subscribers. (2009). [Online] Available: http://www.itu.int/ITUD/icteye/Reporting/ShowReportFrame.aspx?ReportName=/WTI/InformationTechnology Public\&RP_intYear $=2008 \& R P \_$intLanguageID $=1$

Jaffee, L. (2007). Follow the money. Promo Magazine. [Online] Available: $\mathrm{http}: / /$ promomagazine.com/mag/marketing_follow_money_2/Magazine

Mackenzie, S. B., \& Lutz, R. J. (1989). An empirical examination of the structural antecedents of attitude toward the ad in an advertising pretesting context. Journal of Marketing, 53(2), 48-65. http://dx.doi.org/10.2307/1251413

McQuail, D. (1983). Mass communication theory: An introduction. London: Sage.

Moldovan, S. E. (1985). Copy factors related to persuation scores. Journal of Advertising Research, 24(6), 16-22.

Nasco, S. A., \& Bruner, G. C. (2008). Comparing consumer responses to advertising and non-advertising mobile communications. Psychology \& Marketing, 25(8), 821-837. http://dx.doi.org/10.1002/mar.20241

$\mathrm{Ng}$, S. (2010). Cultural orientation and brand dilution: Impact of motivation level and extension typicality. Journal of Marketing Research, 47, 186-198. http://dx.doi.org/10.1509/jmkr.47.1.186

Ngai, E. W. T., \& Gunasekaran, A. (2007). A review for mobile commerce research and applications. Decision Support Systems, 43, 3-15. http://dx.doi.org/10.1016/j.dss.2005.05.003

Nysveen, H., Pedersen, P. E., Thorbjornsen, H., \& Berthon, P. (2005). Mobilizing the brand. Journal of Service Research, 7(3), 257-276. http://dx.doi.org/10.1177/1094670504271151

O'Donnell, J. (2006). Gen Y sits on top of consumer food chain: They're savvy shoppers with money and influence. USA Today, $3 B$.

Okazaki, S. (2005). Mobile advertising adoption by multinationals: Senior executives` initial responses. Internet Research, 15(2), 160-180. http://dx.doi.org/10.1108/10662240510590342

Park, C., \& Jun, J. K. (2003). A cross-cultural comparison of Internet buying behavior: Effects of Internet usage, perceived risks, and innovativeness. International Marketing Review, 20(5), 234-553. http://dx.doi.org/10.1108/02651330310498771 
Rettie, R., Grandcolas, U., \& Deakins, B. (2005). Text message advertising: Response rates and branding effects. Journal of Targeting, Measurement and Analysis for Marketing, 13(4), 304-312. http://dx.doi.org/10.1057/palgrave.jt.5740158

Ryu, G., Lim, E. A. C., Tan, L. T. L., \& Han, Y., J. (2007). Preattentive processing of banner advertisements: The role of modality, location, and interference. Electronic Commerce Research and Applications, 6(1). http://dx.doi.org/10.1016/j.elerap.2005.11.001

Self, C. S. (1996). An integrated approach to communication theory and research. Mahwah, NJ: Erlbaum.

Siau, K., \& Shen, Z. (2003). Building customer trust in mobile commerce. Communications of the ACM, 46(4), 91-94. http://dx.doi.org/10.1145/641205.641211

Sullivan, P., \& Heitmeyer, J. (2008). Looking at gen y shopping preferences and intentions: Exploring the role of experience and apparel involvement. International Journal of Consumer Studies, 32(285-295). http://dx.doi.org/10.1111/j.1470-6431.2008.00680.x

Taylor, C. R., Miracle, G. E., \& Wilson, R. D. (1997). The impact of information level on the effectiveness of U.S. and Korean television commercials. Journal of Advertising, 26(1), 1-18.

Tran, K. T. L. (2008). Retailing's sweet spot: stores look to lure millennial generation. WWD: Women's Wear Daily, 196(2), 1.

Tsang, M. M., Ho, S. C., \& Liang, T. P. (2004). Consumer attitudes toward mobile advertising: An empirical study. International Journal of Electronic Commerce, 8(3), 65-78.

Venkatacharya, P., Rice, S., \& Bezuayehu, L. (2009). Designing for the Next Generation: Generation-Y Expectations. In M. Smith \& G. Salvendy (Eds.), Human Interface and the Management of Information. Designing Information Environments (Vol. 5617, pp. 190-196): Springer Berlin / Heidelberg.

Wei, R., \& Leung, L. (1998). Owning and using new media technology as predictors of quality of life. Telematics and Informatics, 15(4), 237-251. http://dx.doi.org/10.1016/s0736-5853(98)00008-2

$\mathrm{Xu}$, D. J. (2006). The influence of personalization in affecting consumer attitudes toward mobile advertising in China. Journal of Computer Information System, 47(2), 9-19.

Table 1. Reliability Test $(\mathrm{N}=407)$

\begin{tabular}{|l|c|c|}
\hline Variables & $n^{\mathrm{a}}$ & $\alpha^{\mathrm{b}}$ \\
\hline Entertainment & 5 & .90 \\
\hline Informativeness & 7 & .89 \\
\hline Irritation & 5 & .73 \\
\hline Credibility & 3 & .72 \\
\hline
\end{tabular}

Scale range: $1=$ Strongly disagree; $7=$ Strongly agree, ${ }^{\mathrm{a}}$ Number of items; ${ }^{\mathrm{b}}$ Cronbach`s $\alpha$ 
Table 2. Demographic Characteristics $(\mathrm{N}=407)$

\begin{tabular}{|c|c|c|c|c|}
\hline & \multicolumn{2}{|c|}{ U.S. } & \multicolumn{2}{|c|}{ Korea } \\
\hline & Frequency & Percent & Frequency & Percent \\
\hline \multicolumn{5}{|l|}{ Gender } \\
\hline Female & 176 & 88.0 & 141 & 68.1 \\
\hline Male & 24 & 12.0 & 66 & 31.9 \\
\hline \multicolumn{5}{|l|}{ Age } \\
\hline 17 to 20 & 66 & 33.0 & 97 & 46.9 \\
\hline 21 to 25 & 123 & 61.5 & 94 & 45.4 \\
\hline 26 to 30 & 11 & 5.5 & 16 & 7.7 \\
\hline \multicolumn{5}{|l|}{ Major } \\
\hline Business & 2 & 1.0 & 38 & 18.4 \\
\hline Fashion Merchandising & 120 & 60.0 & 0 & 0.0 \\
\hline Fashion Design Information & 0 & 0.0 & 81 & 39.1 \\
\hline Food Engineering & 0 & 0.0 & 25 & 12.1 \\
\hline Hospitality & 49 & 24.5 & 0 & 0.0 \\
\hline Psychology & 0 & 0.0 & 24 & 11.6 \\
\hline Others & 29 & 14.5 & 39 & 18.8 \\
\hline \multicolumn{5}{|l|}{ Academic classification } \\
\hline Freshman & 14 & 7.0 & 108 & 52.2 \\
\hline Sophomore & 35 & 17.5 & 32 & 15.5 \\
\hline Junior & 60 & 30.0 & 26 & 12.6 \\
\hline Senior & 87 & 43.5 & 40 & 19.3 \\
\hline Graduate student & 4 & 2.0 & 1 & 0.5 \\
\hline \multicolumn{5}{|l|}{ Received surveys specified } \\
\hline SMS & 100 & 50.0 & 102 & 49.3 \\
\hline MMS & 100 & 50.0 & 105 & 50.7 \\
\hline
\end{tabular}


Table 3. Mobile Behaviors $(\mathrm{N}=407)$

\begin{tabular}{|c|c|c|c|c|}
\hline \multirow[t]{2}{*}{ Country } & \multicolumn{2}{|c|}{ U.S. } & \multicolumn{2}{|c|}{ Korea } \\
\hline & Frequency & Percent & Frequency & Percent \\
\hline \multicolumn{5}{|l|}{ Have a mobile phone } \\
\hline Yes & 200 & 100.0 & 207 & 100.0 \\
\hline No & 0 & 0.0 & 0 & 0.0 \\
\hline \multicolumn{5}{|l|}{ Money spent for mobile services monthly } \\
\hline Less than $\$ 10$ & 22 & 11.0 & 95 & 45.9 \\
\hline$\$ 11$ to $\$ 30$ & 14 & 7.0 & 50 & 24.2 \\
\hline$\$ 31$ to $\$ 50$ & 30 & 15.0 & 41 & 19.8 \\
\hline$\$ 51$ to $\$ 70$ & 40 & 20.0 & 14 & 6.8 \\
\hline$\$ 71$ to $\$ 90$ & 41 & 20.5 & 5 & 2.4 \\
\hline$\$ 91$ to $\$ 110$ & 29 & 14.5 & 2 & 1.0 \\
\hline More than $\$ 111$ & 24 & 12.0 & 0 & 0.0 \\
\hline \multicolumn{5}{|l|}{ Receive M-advertising messages in one week } \\
\hline Never & 89 & 44.5 & 23 & 11.1 \\
\hline 1 to 10 & 93 & 46.5 & 154 & 74.4 \\
\hline 11 to 20 & 7 & 3.5 & 21 & 10.1 \\
\hline 21 to 30 & 2 & 1.0 & 5 & 2.4 \\
\hline 31 to 40 & 1 & 0.5 & 2 & 1.0 \\
\hline 41 to 50 & 0 & 0.0 & 1 & 0.5 \\
\hline More than 51 & 8 & 4.0 & 1 & 0.5 \\
\hline \multicolumn{5}{|l|}{ Receive apparel M-advertising messages } \\
\hline Yes & 55 & 27.5 & 113 & 54.6 \\
\hline No & 145 & 72.5 & 94 & 45.4 \\
\hline \multicolumn{5}{|l|}{$\begin{array}{l}\text { Money spent for apparel in brick-and-mortar } \\
\text { monthly }\end{array}$} \\
\hline Less than $\$ 25$ & 37 & 18.5 & 56 & 27.1 \\
\hline$\$ 26$ to $\$ 75$ & 61 & 30.5 & 79 & 38.2 \\
\hline$\$ 76$ to $\$ 125$ & 64 & 32.0 & 42 & 20.3 \\
\hline$\$ 126$ to $\$ 175$ & 18 & 9.0 & 20 & 9.7 \\
\hline More than $\$ 176$ & 20 & 10.0 & 10 & 4.8 \\
\hline \multicolumn{5}{|l|}{ Money spent for apparel at online retailers monthly } \\
\hline Less than $\$ 25$ & 120 & 60.0 & 77 & 37.2 \\
\hline$\$ 26$ to $\$ 75$ & 41 & 20.5 & 72 & 34.8 \\
\hline$\$ 76$ to $\$ 125$ & 27 & 13.5 & 42 & 20.3 \\
\hline$\$ 126$ to $\$ 175$ & 4 & 2.0 & 10 & 4.8 \\
\hline More than $\$ 176$ & 8 & 4.0 & 6 & 2.9 \\
\hline \multicolumn{5}{|l|}{ Use of mobile phone } \\
\hline Make and receive phone calls & 198 & 99.0 & 195 & 94.2 \\
\hline Send and receive text messages & 192 & 96.0 & 193 & 93.2 \\
\hline Send and receive e-mail & 123 & 61.5 & 12 & 5.8 \\
\hline Play games & 119 & 59.5 & 87 & 42.0 \\
\hline Receive advertisements and sales promotions & 49 & 24.5 & 42 & 20.3 \\
\hline GPS & 103 & 51.5 & 7 & 3.4 \\
\hline Other & 31 & 15.5 & 16 & 7.7 \\
\hline
\end{tabular}


Table 4. Two-Way ANOVA Analyses

\begin{tabular}{|l|l|c|c|c|c|c|}
\hline Variable & Effect & $\begin{array}{c}\text { Sum of } \\
\text { Squares }\end{array}$ & df & $\begin{array}{c}\text { Mean } \\
\text { Square }\end{array}$ & F & p \\
\hline Entertainment & Corrected Model & 26.908 & 3 & 8.969 & 4.982 & $.002^{* *}$ \\
\hline & Modality & 8.645 & 1 & 8.645 & 4.802 & $.029^{*}$ \\
\hline & Culture & 17.123 & 1 & 17.123 & 9.512 & $.002^{* *}$ \\
\hline Informativeness & Corrected Model & 93.321 & 3 & 31.107 & 22.602 & $.000^{* * *}$ \\
\hline & Modality & 1.505 & 1 & 1.505 & 1.094 & .296 \\
\hline & Culture & 90.720 & 1 & 90.720 & 65.916 & $.000^{* * *}$ \\
\hline & Corrected Model & 99.928 & 3 & 33.309 & 29.135 & $.000^{* * *}$ \\
\hline & Modality & 2.583 & 1 & 2.283 & 2.259 & .134 \\
\hline Credibility & Culture & 96.608 & 1 & 96.608 & 84.502 & $.000^{* * *}$ \\
\hline & Corrected Model & 122.900 & 3 & 40.967 & 25.140 & $.000^{* * *}$ \\
\hline & Modality & .142 & 1 & .142 & .087 & .768 \\
\hline
\end{tabular}

$* p<.05, * * p<.01, * * * p<.001$

Table 5. Descriptive Statistics for Two-Way ANOVA Analyses

\begin{tabular}{|c|c|c|c|c|c|}
\hline Variable & Country & Modality & $\mathrm{M}$ & SD & $\mathrm{N}$ \\
\hline \multirow[t]{9}{*}{ Entertainment } & \multirow{3}{*}{ U.S. } & SMS & 3.21 & 1.43 & 100 \\
\hline & & MMS & 3.39 & 1.32 & 100 \\
\hline & & Total & 3.30 & 1.38 & 200 \\
\hline & \multirow{3}{*}{ Korea } & SMS & 2.69 & 1.28 & 102 \\
\hline & & MMS & 3.10 & 1.33 & 105 \\
\hline & & Total & 2.90 & 1.32 & 207 \\
\hline & \multirow{3}{*}{$\begin{array}{l}\text { U.S. \& } \\
\text { Korea }\end{array}$} & SMS & 2.95 & 1.38 & 202 \\
\hline & & MMS & 3.24 & 1.33 & 205 \\
\hline & & Total & 3.10 & 1.36 & 407 \\
\hline \multirow[t]{9}{*}{ Informativeness } & \multirow{3}{*}{ U.S. } & SMS & 4.65 & 1.31 & 100 \\
\hline & & MMS & 4.66 & 1.13 & 100 \\
\hline & & Total & 4.65 & 1.22 & 200 \\
\hline & \multirow{3}{*}{ Korea } & SMS & 3.59 & 1.18 & 102 \\
\hline & & MMS & 3.83 & 1.06 & 105 \\
\hline & & Total & 3.71 & 1.12 & 207 \\
\hline & \multirow{3}{*}{$\begin{array}{l}\text { U.S. \& } \\
\text { Korea }\end{array}$} & SMS & 4.11 & 1.35 & 202 \\
\hline & & MMS & 4.23 & 1.17 & 205 \\
\hline & & Total & 4.17 & 1.26 & 407 \\
\hline \multirow[t]{9}{*}{ Irritation } & \multirow{3}{*}{ U.S. } & SMS & 3.92 & 1.08 & 100 \\
\hline & & MMS & 3.67 & 1.04 & 100 \\
\hline & & Total & 3.79 & 1.07 & 200 \\
\hline & \multirow{3}{*}{ Korea } & SMS & 4.80 & 1.16 & 102 \\
\hline & & MMS & 4.74 & 0.98 & 105 \\
\hline & & Total & 4.77 & 1.07 & 207 \\
\hline & \multirow{3}{*}{$\begin{array}{l}\text { U.S. \& } \\
\text { Korea }\end{array}$} & SMS & 4.37 & 1.20 & 202 \\
\hline & & MMS & 4.21 & 1.14 & 205 \\
\hline & & Total & 4.29 & 1.18 & 407 \\
\hline \multirow[t]{9}{*}{ Credibility } & \multirow{3}{*}{ U.S. } & SMS & 4.05 & 1.35 & 100 \\
\hline & & MMS & 3.86 & 1.30 & 100 \\
\hline & & Total & 3.95 & 1.33 & 200 \\
\hline & \multirow{3}{*}{ Korea } & SMS & 2.75 & 1.25 & 102 \\
\hline & & MMS & 3.00 & 1.20 & 105 \\
\hline & & Total & 2.88 & 1.23 & 207 \\
\hline & \multirow{3}{*}{$\begin{array}{l}\text { U.S. \& } \\
\text { Korea }\end{array}$} & SMS & 3.39 & 1.45 & 202 \\
\hline & & MMS & 3.42 & 1.32 & 205 \\
\hline & & Total & 3.41 & 1.39 & 407 \\
\hline
\end{tabular}

